\title{
Uma abordagem conceitual da teoria do diálogo institucional na jurisdição constitucional portuguesa
}

\author{
A conceptual approach to the theory of institutional \\ dialogue in the constitutional Portuguese jurisdiction
}

\author{
PAULO ROBERTO BARBOSA RAMOS ${ }^{1}$ \\ paulorbr@uol.com.br \\ PEDRO TROVÃO DO ROSÁRIO² \\ prosario@autonoma.pt \\ PEDRO NILSON MOREIRA VIANA ${ }^{3}$ \\ pedro.moreira.viana@hotmail.com \\ GALILEU - REVISTA DE DIREITO E ECONOMIA - e-ISSN 2184-1845 \\ Volume XX $\cdot 1^{\text {st }}$ January Janeiro $-30^{\text {TH }}$ June Junho $2019 \cdot$ pp. 7-36 \\ DOI: ??? \\ Submitted on March 3 ${ }^{\text {st }}, 2019 \cdot$ Accepted on May 28 $8^{\text {th }}, 2019$ \\ Submetido em 13 de Março, 2019 . Aceite a 28 de Maio, 2019
}

RESUMO O constitucionalismo, enquanto resultado de uma série de movimentos de racionalização do Estado, serviu como indispensável vetor intelectual de limitação do exercício do poder do governante ainda no século XVII, por meio da previsão de direitos e garantias firmados em leis e declarações. Contudo, se antes a sua grande força motriz girava em torno da limitação do poder estatal e da separação de poderes, hoje os problemas são

1 Possui Graduação em Direito pela Universidade Federal do Maranhão (1992), Mestrado em Direito pela Universidade Federal de Santa Catarina (1997), Doutorado em Direito Constitucional pela Pontifícia Universidade Católica de São Paulo (2001) e Pós-Doutorado em Direito Constitucional pela Universidade de Granada - Espanha (2010/2011). É professor da Universidade Federal do Maranhão, Coordenador do Núcleo de Estudos de Direito Constitucional dessa mesma instituição, Professor Pesquisador do Centro Universitário do Maranhão e Promotor de Justiça de Controle Externo da Atividade Policial do Ministério Público do Estado do Maranhão, Brasil.

2 Doutor em Fundamentos de Direito Político pela UNED, Espanha (2009). Advogado. Diretor do Departamento de Direito da Universidade Autónoma de Lisboa (UAL) e Vice-Presidente da Fundación Universitária Internacional. Membro Internacional da Comissão de Direito à Educação na Seccional da Ordem dos Advogados do Brasil do Estado do Rio de Janeiro. Membro Emérito da Comissão de Estudos de Direito Comparado Ordem dos Advogados do Brasil (Rio de Janeiro - 57. a subsecção). Investigador registado na Fundação para Ciência e a Tecnologia (FCT).

3 Acadêmico do curso de Direito da Universidade Federal do Maranhão (UFMA), Brasil. É membro pesquisador do Programa de Ensino Tutorial PET Direito da Universidade Federal do Maranhão (PET/UFMA). Pesquisador do Núcleo de Estudos de Direito Constitucional (NEDC), vinculado ao Programa de Pós-Graduação em Direito e Instituições do Sistema de Justiça da Universidade Federal do Maranhão (PPGDIR/UFMA). Pesquisador visitante junto à Universidade Autônoma de Lisboa (UAL), Portugal. Bolsista da Fundação de Amparo à Pesquisa e ao Desenvolvimento Científico e Tecnológico do Maranhão - FAPEMA. 
muito mais desafiadores. É que a pluralidade de interesses e de direitos nas sociedades atuais vem inspirando uma nova visão político-jurídica que contempla arranjos institucionais capazes de conduzir a um exercício mais democrático da interpretação constitucional, isto é, alternativas nas quais a significação dos direitos é feita a partir de uma construção racional entre os Poderes instituídos, inexistindo assim, a figura de um ramo de governo supremo a todos os outros. A teoria do Diálogo Institucional, objeto da presente análise, é o mais notável destes novos arranjos. Definível, em síntese, como um sistema no qual as grandes decisões de um tribunal constitucional podem ser rediscutidas por um órgão legislativo, foi primeiramente adotado pela constituição canadense na década de 1980, e hoje tem suscitado considerável debate acadêmico sobre seus potenciais e falhas. Assim, o presente estudo, a partir de um viés essencialmente bibliográfico e qualitativo, analisa a origem histórica e conceitual da referida teoria buscando evidenciar como as estruturas de poder podem dialogar, e em que medida o diálogo público pode ser presente no sistema de definição dos direitos em Portugal.

PALAVRAS-CHAVE Diálogo Institucional. Construção Racional dos Direitos nas Democracias. Judicial Review.

ABSTRACT Constitutionalism, as a result of a series of state rationalization movements, served as an indispensable intellectual vector, limiting the exercise of the ruler's power in the seventeenth century, specially through the provision of rights and guarantees in laws and declarations.

However, if its great driving force used to be the limitation of state power and the separation of powers, today the problems are much more challenging. That's a result of the plurality of interests and rights in today's societies which has inspired a new political-juridical vision that contemplates institutional arrangements capable of leading to a more democratic exercise of constitutional interpretation, that is, alternatives in which the meaning of rights is result from of a rational construction between the Powers instituted, thus lacking the figure of one supreme branch of government. The theory of Institutional Dialogue, object of the present analysis, is the most remarkable of these new arrangements. Definable, in short, as a system in which major decisions of a constitutional court can be redrawn by a legislative body, it was first adopted by the Canadian constitution in the 1980s, and today has elicited considerable academic debate about its potentials and failures. Thus, the present study, based on an essentially bibliographic and qualitative bias, analyzes the historical and conceptual origin of this theory, seeking to show how power structures can dialogue, and to what extent public dialogue can be present in the system of definition of rights in Portugal.

KEYWORDS Institutional Dialogue. Ration Construction of Rights in Democracies. Judicial Review. 
Uma abordagem conceitual da teoria do diálogo institucional na jurisdição constitucional portuguesa

PAULO ROBERTO BARBOSA RAMOS | PEDRO TROVÃO DO ROSÁRIO | PEDRO NILSON MOREIRA VIANA

GALILEU - e-ISSN 2184-1845 - Volume XX - Issue Fascículo 1 - 15t January Janeiro - 30th June Junho $2019 \cdot$ pp. 7-36

\section{Introdução}

A busca pelo equilíbrio institucional levada a cabo nas origens da organização política dos Estados Unidos aduziu necessariamente pelo controle do poder através de seu escalonamento, seja ele entre governo central e local, seja ainda entre poderes de estado com funções repartidas para legislar, governar e julgar.

Essa noção de controle do poder estatal estatuiu a separação harmônica de papéis que cada ramo de governo deveria exercer, de sorte que é possível identificar neste modelo de organização, um imbricado sistema de competências repartidas entre as várias esferas de decisão política.

Em que pese não terem os americanos inventado a tríplice estrutura de funções do Estado, a sua Constituição de 1787 apresenta características que expressam fortes tendências ao controle, dentre as quais se destacam a instituição de um plano horizontal entre os poderes de estado e a capacidade de tribunais de justiça invalidarem leis e atos normativos através de um singular sistema de controle de constitucionalidade.

O paradigma da supremacia judiciária firmado primeiramente na Constituição americana apesar de também fazer parte da estrutura política de vários estados democráticos, como o Brasil, enfrentou e ainda enfrenta incisivas objeções. É que a última palavra do sistema do judicial review pode promover, em alguma medida, a ocorrência de fenômenos como o ativismo judicial e a judicialização política, levando a doutrina a uma busca por formas alternativas de definição do direito. Neste aspecto, como produto histórico dos avanços e retrocessos civilizatórios, hoje, existem vários arranjos institucionais que, desde a doutrina judicialista, pretendem conciliar independência e harmonia entre o poder judiciário e o poder legislativo.

Essas novas tendências estruturais, em breve síntese, surgem a fim de conformar o instituto do judicial review a uma realidade em que cada vez mais se exige dos poderes constituídos uma atuação dinâmica e ágil, apta a fazer frente às multitudinárias pluralidades de conflitos jurídicos da sociedade contemporânea.

Dentre as muitas correntes ideológicas opostas ao poder revisional exclusivo dos tribunais constitucionais, destaca-se a teoria do Diálogo Institucional. Esse complexo sistema de controle de constitucionalidade foi considerado por Peter Hogg e Alison Bushell como uma invenção única no mundo jurídico. Mais reconhecidamente adotado no Canadá, a estrutura dialógica lá efetivada entre Suprema Corte e Parlamento retirou do Poder Judiciário parte da prerrogativa da última palavra, submetendo as suas decisões a um processo de eventual ressignificação por parte do legislativo.

Isto é, referido processo estabeleceu um diálogo público onde valores encartados na Constituição são alvo de um modelo democraticamente regulado no qual a significação 
Uma abordagem conceitual da teoria do diálogo institucional na jurisdição constitucional portuguesa

PAULO ROBERTO BARBOSA RAMOS | PEDRO TROVÃO DO ROSÁRIO | PEDRO NILSON MOREIRA VIANA

GALILEU - e-ISSN 2184-1845 - Volume XX - Issue Fascículo 1 - 15t January Janeiro - 30th June Junho $2019 \cdot$ pp. 7-36

dos direitos é feita a partir de uma construção racional entre os poderes (poderes) instituídos, inexistindo assim, a figura de um ramo de governo supremo a todos os outros. Neste modelo estrutural, seja pelo acordo ou pelo desacordo, o direito é fruto do diálogo consciente, um debate público e qualificado acerca de seu conteúdo.

Lançadas tais bases, diante das peculiaridades históricas do constitucionalismo, impõe-se analisar conceitual e historicamente se é possível haver diálogo institucional no sistema de definição dos direitos em Portugal.

\section{A construção racional dos direitos e o constitucionalismo contemporâneo}

Traçando-se uma rápida linha do tempo pelos últimos séculos, é possível constatar que o constitucionalismo é o resultado prático de uma série de movimentos que fomentaram a ideia central de racionalização do Estado e de limitação do exercício do poder do governante, por meio da previsão de direitos e garantias firmados em leis e declarações.

Em breve análise, estes movimentos abrangem diversas correntes filosóficas, políticas e sociais que tiveram como base a Inglaterra do século XVII, aliado ao surgimento do Bill of Rights, tendo-se intensificado ao final do século XVIII por conta principalmente da Revolução Francesa (1789-1799) e da promulgação da Constituição dos Estados Unidos da América (1777).

Tais correntes tiveram como expoentes alguns dos mais relevantes pensadores modernos conhecidos mundialmente como, e.g., John Locke, Montesquieu e Rousseau, influenciadores do pensamento liberal que fomentou a queda de regimes absolutistas por intermédio da conceção de que as pessoas detêm autodeterminação suficiente para, em um pacto coletivo, abdicar de certos direitos e liberdades a fim de constituir um governo investido por meio da adesão voluntária e não mais pela força.

Por ilustrativo, Jorge Miranda ${ }^{4}$ expressa com precisão a mudança paradigmática que conduziu ao fenômeno em análise:

"Em vez da tradição, o contrato social; em vez da soberania do príncipe, a soberania nacional e a lei como expressão da vontade geral; em vez do exercício do poder por um só, o exercício do poder por muitos; em vez de súditos, cidadãos, e atribuição a todos os homens, apenas por serem homens, de direitos consagrados nas leis". 
Mas, afinal de contas, em quê consistiu o constitucionalismo e, em que medida, sua presença ainda é importante para as democracias atuais? Em seu aspeto teórico, o constitucionalismo ostenta a característica de conceito multifacetário na medida em que pode ser compreendido a partir de mais de uma vertente de análise. Por exemplo, são recorrentes desde perspetivas culturais, históricas à normativo-dogmáticas.

Neste aspecto, Peter Häberle ${ }^{5}$, por exemplo, considera o constitucionalismo como "processo cultural e historicamente condicionado através do qual é possível limitar o poder estatal substantivo as regras e ritos racionalmente acordados." Noutro modo, Celso Ribeiro Bastos $^{6}$, considera ser o constitucionalismo "fenômeno social essencialmente dotado de caráter jurídico". Já autores como Eric Kaufmann e Horst Ehmke, aduzem, respectivamente, que este foi um movimento dirigido contra o absolutismo monárquico, a fim limitar o poder estatal a partir do compartilhamento do exercício da soberania com o Parlamento, tendo como finalidade essencial, a organização de um processo vital de liberdade.

Contudo, apesar das várias perspetivas de abordagem, é possível traçar a partir dos referenciais mencionados, características comuns quanto ao surgimento do movimento constitucionalista. Isto é, não obstante, manifestarem perspetivas finalísticas diferentes do conceito do fenômeno constitucional, há relativa convergência sobre suas razões determinantes. Nos dizeres de Jorge Miranda7, "apesar de concebido em termos racionais e até desejavelmente universais, [o constitucionalismo] na sua realização histórica, não pode desprender-se de certa situação socioeconômica e sociopolítica".

Em regra, o historicismo do movimento constitucionalista evidenciado por Miranda, é compreendido pelos autores como elemento fundacional de um amplo processo sociocultural de difusão de ideais que almejavam o estabelecimento de um processo de "domesticação racional do poder" como premissa antropológica de salvaguarda da dignidade humana.

A este respeito, ao pretender legitimar o controle do poder estatal a um consenso fundamental, o constitucionalismo apresenta condições de sustentabilidade singulares e condicionadas ao resultado prático do arranjo de variáveis sociais e históricas presentes de modo particular em cada organização humana. Compreender a influências de tais variáveis sobre a dinâmica dos mecanismos institucionais fixados em uma constituição é essencial para vislumbrar o futuro do constitucionalismo no mundo contemporâneo. Em que pese reconhecidamente plural, na acepção de Peter Häberle, o constitucionalismo precisa ser

\footnotetext{
5 HÄRBELLE, Peter - Novos Horizontes e Novos Desafios do Constitucionalismo. In Anuário Português de Direito Constitucional - Vol. V. Coimbra: Coimbra Editora, 2006, pp. 37-62.

6 BASTOS, Celso Ribeiro - Curso de Direito Constitucional. 22. ${ }^{\mathrm{a}}$ ed. São Paulo: Saraiva, 2010.

7 MIRANDA, Jorge - Manual de Direito Constitucional. 1. ${ }^{a}$ ed. Coimbra: Coimbra Editora, 2008, p. 98.
} 
dotado de pelo menos seis elementos concretos que viabilizam sua existência e efetividade em maior ou menor grau.

Segundo o autor, o estado efetivamente constitucional precisa i) assegurar uma democracia pautada no pluralismo, isto é, materialmente assegurar enquanto fundamental, o direito à liberdade e à diversidade de ideias e suas expressões; ii) estabelecer direitos fundamentais; iii) separar poderes de governo em funções e atividades distintas, bem como ainda; iv) garantir uma atividade administrativa minimamente organizada, com a divisão de competências e ritos processuais para aplicação do direito; v) promover o "rule of law", e vi) assegurar proteção jurídica efetiva, através da independência dos tribunais, com a garantia de uma justiça constitucional capaz de interpretar desimpedidamente a constituição e o direito. Cumpre observar que tais condições tem um caráter essencialmente indicativo.

Logo, diante das várias diferenças históricas, culturais e sociopolíticas presentes nas mais variadas organizações políticas, é que Canotilho ${ }^{8}$, a este respeito, considera que existe não somente um, mas sim, "múltiplos processos constitucionalistas, com características e desafios próprios". Porém, para além de tal carga histórica, o constitucionalismo hoje ostenta característica de um conceito generalizado universalmente, e que, por tal universalização, pode referir-se a várias multiplicidades do gênero "Estado Constitucional". Por este motivo é que ao passo que se revela enquanto marco histórico civilizatório, é também projeto humano situado em constante processo de desenvolvimento, movido pelas novas realidades e necessidades. Se antes a grande força motriz do constitucionalismo girava em torno da limitação do poder estatal e da separação de poderes, condições estas de sustentabilidade relativamente difundidas pelo mundo como desejáveis, hoje os problemas são muito mais complexos. Neste aspeto, Jorge Miranda9 destaca:

"Ao passo que o Estado atinge sua máxima expansão, desenvolve-se a estruturação da comunidade internacional, através de agrupamentos de Estados com funções específicas que adquirem autonomia relativa a eles [...]. Nasce a proteção internacional dos direitos do homem, tendo por causas a tendência para a humanização, e sobretudo, o repúdio da pressão feita por regimes políticos de vários sinais ideológicos e a consciência universal da dignidade humana que vai se consolidando. É certo que no início do século XXI, o panorama político-constitucional é, de novo, de grandes transformações e instabilidades. Quase todos os regimes totalitários ou autoritários entraram em declínio irreversível e

8 CANOTILHO, J. J. G. - Direito constitucional e teoria da constituição. 7. ed. Coimbra: Almedina, 2003, p. 64.

9 MIRANDA, Jorge - Manual de Direito Constitucional. 1. a ed. Coimbra: Coimbra Editora, 2008, p. 35. 
a democracia representativa dir-se-ia agora prevalecer. Todavia, não se denotam poucas as contradições e indefinições de ostenta [...]. Não se chegou, pois, ao fim da história - muito longe disso; apenas se chegou ao fim de certa era ou a um momento de transição, com todas as virtualidades que, apesar de tudo, pode conter".

Vê-se, portanto, que o intenso processo de globalização que a humanidade vivencia aumenta a complexidade da organização humana. Isso exige cada vez mais compreender como os grandes sistemas constitucionais dão solução a problemas jurídicos igualmente mais complexos. Estes novos desafios impostos ao constitucionalismo hoje, sobretudo no tocante a compreensão e delimitação do conteúdo de direitos, têm permitido a construção de alternativas às tradicionais estruturas de governo.

Certo é que a construção de tais alternativas é fator de equilíbrio chave para o controle do poder, haja vista que é consequência inescapável para a construção racional dos direitos nas democracias a inexistência de um ramo de governo supremo a todos os outros. Cumpre notar que a abertura de conhecimento que o novo cenário de fluidez teórica permite em relação a compreensão do sentido constitucional, vem inspirando uma nova visão de constitucionalismo que contempla arranjos institucionais capazes de conduzir a um exercício mais democrático da hermenêutica constitucional.

Conhecidas como correntes de cooperação, estas compreensões mais democráticas da atividade de interpretação concebem que a realização do texto constitucional não pode mais ser pensada de forma singular, devendo se reconhecer a multiplicidade de atores envolvidos nesse processo como condição de eficácia da própria constituição. Neste aspeto, esclarece Peter Häberle ${ }^{10}$ :

"Uma teoria constitucional se concebe como ciência da experiência e deve estar com condições de, decisivamente, explicar os grupos concretos de pessoas e os fatores que formam o espaço público (Öffentlichkeit) (...). A interpretação é um processo aberto. Não é, pois, um processo de passiva submissão, nem se confunde com a receção de uma ordem. A interpretação conhece possibilidades e alternativas diversas pois que se insere em um contexto democrático no qual não pode haver interrupção e não existe e nem deve existir dirigentes (...). Se se reconhece que a norma não é uma decisão prévia, simples e acabada, há de se indagar sobre os participantes no seu desenvolvimento funcional".

10 HÄRBELLE, Peter - Hermenêutica Constitucional - A sociedade aberta dos intérpretes da Constituição: contribuição para a interpretação pluralista e "procedimental" da Constituição. Porto Alegre: Sérgio António Fabris Editor, 2002, p. 36. 
Assim, esta linha de estruturação do constitucionalismo atual, pretende legitimar relações de cooperação, distanciando-se cada vez mais da tradicional ideia de supremacia, possibilitando-se a comunicação "a partir do reconhecimento de alteridade, sem que isso signifique uma mera convergência" ${ }^{11}$. Esta conceção permite ao órgão responsável pelo exercício da jurisdição constitucional a observância do direito comparado, propiciando o nascimento do que alguns denominam de diálogo judicial. Atualmente, desde a doutrina judicialista, existem variados arranjos que pretendem adotar dinâmicas de restabelecimento integral da primazia legislativa na interpretação constitucional, ou uma mitigação das competências revisionais do poder judiciário. Dentre estas novas tendências destaca-se a teoria dos diálogos institucionais - objeto da discussão que se segue.

\section{O judicial review e a jurisdição constitucional na era das democracias}

As bases estruturais de formação política dos Estados Unidos apontam desde suas origens para uma dogmática controladora do poder do Estado através de seu escalonamento em variadas funções de governança. Embora não se atribua exclusivamente aos estadunidenses o advento do sistema de freios e contrapesos, por certo, ao compulsar as teses expedidas na obra "The Federalists Papers", fica claro verificar que a partir da Constituição americana de 1787 inaugurou-se um efetivo mecanismo de controle constitucional que serve de inspiração para diversas ordenações políticas.

A medida em que as funções de cada instituição se dividem em mico espaços de poder, pautados em regras rígidas expressas na lei e na constituição, mais fácil se torna controlar o processo de tomada de decisão do estado e assim, afastar as tendências centralizadoras que lhe são inerentes. É sob este particular que a natureza da divisão institucional do poder resulta no advento de um ramo judiciário que serve de árbitro das disputas oriundas da interpretação ou estrutura do texto constitucional. Muito embora o paradigma da supremacia judiciária faça parte da estrutura política de várias democracias, este modelo judiciário de definição do direito enfrentou e ainda enfrenta incisivas objeções.

Como bem sistematizou Eduardo Vieytez ${ }^{12}$, a consagrada última palavra do sistema do judicial review representou a distinção histórica do modo de garantir juridicamente os direitos fundamentais, de sorte que em países de tradição da common law, as estruturas políticas adotam modelos parlamentares de definição do direito.

11 NEVES, Marcelo - Transconstitucionalismo. São Paulo: WMF Martins Fontes, 2013, p. 25.

12 VIEYTEZ, Eduardo J. Ruiz - La excepción constitucional australiana: el debate sobre la protección jurídica de los derechos y el modelo del diálogo institucional. In Revista Española de Derecho Constitucional, Madrid. ISSN 0211-5743. N. 95, 2012, pp. 112-114. 
Como observado, contemporaneamente, existem vários arranjos institucionais ${ }^{13}$ que pretendem adotar dinâmicas de restabelecimento integral da primazia legislativa na interpretação constitucional ou a mitigação das competências revisionais do poder judiciário. Dentre estes arranjos estruturais, destaca-se aquele proposto pela teoria dos diálogos institucionais, que surge a fim de conformar o instituto do judicial review a uma realidade onde cada vez mais se exige dos poderes constituídos uma atuação harmônica.

Desta feita, o presente estudo abordará as correntes contra majoritárias ao judicial review mais relevantes no contexto constitucional atual, a fim de traçar em um primeiro momento, a quadra das teorias tensionistas entre controle de constitucionalidade e democracia, bem como analisar as argumentações contrárias à supremacia judicial no contexto da proposta de revalorização legislativa - expressos de sobremodo nas abordagens teóricas de Jeremy Waldron. Em um segundo plano, pretende-se elaborar um breve escorço do desenvolvimento das origens da teoria constitucional dialógica e das implicações do diálogo entre Legislativo e Judiciário à luz dos estudos de Ronald Dworkin.

Com efeito, o contramajoritarismo sustenta o estabelecimento de uma supremacia parlamentar ou mesmo de um compartilhamento funcional entre os poderes públicos da atividade de significância do direito. I.e., esta corrente pretende mitigar ou extinguir a atividade interpretativa de juízes não eleitos. As teses contra majoritárias, em regra, podem ser concebidas em dois grandes grupos, (i) teses que pleiteiam o refreamento do judicial review; (ii) teses que propõe um completo redesenho institucional a fim de criar capacidades específicas dos atores institucionais da interpretação do texto constitucional.

Jeremy Waldron, jus filósofo neozelandês, surge como um dos expoentes mais críticos a atribuição de não eleitos declararem a nulidade de leis aprovadas por corpos legislativos democraticamente instituídos. Porém, em que pese ofereça forte oposição à ideia revisionista, Waldron reconhece como admissível a existência do judicial review, desenvolvendo em seu estudo uma análise da situação do poder revisional existente no século XX, classificando-o em judicial review forte, intermediário e fraco.

A partir desta divisão, o autor cria uma distinção entre judicial review e judicial supremacy. Em regra, o autor considera ser o judicial review uma competência modesta de controle do Poder judiciário sobre os outros Poderes instituídos, enquanto que a conceção de judicial supremacy implica um protagonismo exacerbado do Judiciário nas políticas institucionais: de outra forma, os tribunais constitucionais nesta perspetiva seriam soberanos a todos demais ramos do governo - esta é a conceção veementemente rechaçada por ele.

13 Por ilustrativo cumpre destacar os movimentos do Constitucionalismo Popular e do Departamentalismo, que perquirem a instituição de um processo aberto de interpretação do texto constitucional pelos próprios destinatários, ou pelos diversos poderes de estado. 
De acordo com a perspetiva waldroniana, permitir que os tribunais e seus juízes exerçam o poder revisional indiscriminadamente significa deslocar o autogoverno. Isto porque, segundo ele, as elites judiciárias - intelectualmente dotadas e diretamente influenciadas por interesses políticos -, retirariam dos representantes democráticos o poder de deliberar e decidir sobre as políticas de desenvolvimento na medida em que por controlar sem controle proporcional e simetricamente inverso, o poder judiciário transformar-se-ia em constituinte derivado - decidindo sobre a direção das demais instituições. De certa forma, a partir do problema da soberania ${ }^{14}$ apresentado em Hobbes, a supremacia judicial escapa à ideia de controle parlamentar, "consignando-se o judiciário a voz da constituição, ao passo que seus juízes se transformam em verdadeiros tiranos."

A principal ofensiva de Waldron à supremacia judicial reside na tese contrária a prerrogativa construída de ter o Judiciário a última palavra sobre a Constituição. O autor sugere como solução para o controle da força central de coerção normativo-interpretativa de termos ou direitos vagos, o emprego de chamadas "decisões deliberadas". Contudo, as decisões a que se refere não são decisões judiciais, mas sim decisões políticas.

Assim, é possível afirmar que Waldron, e as correntes contra majoritárias em geral, percebem a deliberação política - através da participação democrática organizada pela regra da decisão majoritária - como não somente o meio de definir políticas públicas, mas ainda como meio de decisão sobre o significado de direitos essenciais dos membros dessa mesma sociedade. O processo político, determina, em sua aceção, não somente as metas públicas a serem atingidas, mas também a distribuição dos direitos fundamentais.

Neste ponto, ao considerar que em tal processo as discordâncias de ponto de vista ideológico e morais são inescapáveis - definidas por ele como circunstâncias de política ${ }^{15}$ - é necessário estabelecer uma autoridade para definir o que é certo ${ }^{16}$. De lógico, a posição de Waldron é aquela que privilegia o parlamento e os demais mecanismos democráticos tradicionais de representação para a adoção de decisões políticas e decisões jurídicas, ainda que elas recaiam sobre a interpretação/significação de princípios.

É que, segundo ele, a forma digna e igualitária de tratar os indivíduos é considerar isonomicamente suas respetivas participações no processo político-democrático de tomada de decisões - possibilitando-se dizer que, apesar do dissenso moral razoável sempre persistir

14 No qual a solução para o poder controlador seria a aplicação do Rule of Law, no qual o Monarca ou o Parlamento detém a prerrogativa de criação e definição do direito.

15 Circunstâncias de justiça poderia ser entendido como o sentimento compartilhado pelos membros da sociedade de que existe a necessidade de estabelecer regras/estruturas de solução de problema controvertidos e discordantes ao passo que precisam agir conjuntamente.

16 É dizer-se: os homens discordam sobre as questões de justiça e precisam ao mesmo tempo tomar decisões em conjunto. 
após a aprovação do texto legislativo, todos os sujeitos partícipes (vencedores/vencidos) aceitarão a nova lei como legítima pois que do seu processo de criação participaram. Portanto, é da posição dos membros legislativos que as mudanças/definições jurídicas e políticas devem ser intencionalmente deliberadas e debatidas (isto é, pelos próprios destinatários da norma, direta ou indiretamente). Contudo, na adoção deste processo, considerando-se a inafastabilidade do dissenso, o critério da vontade da maioria é sempre a saída para a tomada de decisões. Ronald Dworkin, de outro modo, reconhece que a supremacia judicial é um fato histórico da sociedade que considera o poder judiciário como o intérprete final da constituição, cuja compreensão dos direitos fundamentais é a de um ordenamento essencialmente composto de princípios.

O esforço teórico por ele depreendido na obra "Levando os Direitos a Sério" tem como objetivo justificar a legitimidade democrática do judicial review. Em um primeiro momento, é possível afirmar que Dworkin não vê qualquer objeção a invalidação de leis por juízes não eleitos. Em verdade, o autor acredita que este arranjo é capaz de melhorar as estruturas democráticas.

Para Dworkin o direito é essencialmente interpretativo e, neste aspeto, os princípios, por seu turno, permitem aos juízes decidirem os casos concretos. Significa dizer, de certa forma, que o direito só pode ser compreendido no caso concreto, eis que derivaria de um esforço conjunto de interpretação das regras, princípios e das diretrizes políticas. Assim, inevitavelmente, quando uma constituição firma direitos individuais de natureza principiológica - ou seja, quando estabelece direitos, mas não estabelece precisamente no que tais direitos consistem efetivamente ${ }^{17}$, algum organismo de governo deve ter a última palavra sobre o que tal direito deve valer. Melhor clarifica Dworkin ${ }^{18}$ :

"Minha visão é que o Tribunal deve tomar decisões de princípio, não de política - decisões sobre que direitos as pessoas têm sob nosso sistema constitucional, não decisões sobre como se promove melhor o bem-estar geral -, e que deve tomar essas decisões elaborando e aplicando a teoria substantiva da representação, extraída do princípio básico de que o governo deve tratar as pessoas como iguais".

17 Os princípios não almejam estabelecer condicionantes para a sua aplicação, faz tão somente um anúncio para a sua efetivação e aplicação. Já as regras devem ser aplicadas de modo irrestrito, pois se aplica ou não se aplica no caso concreto

18 DWORKIN, Ronald - Taking Rights Seriously. Cambridge: Harvard University Press, 1978, p. 101. 
De acordo com a teoria constitucional de Dworkin, a argumentação jurídica pode ser compreendida em (1) argumentos de princípios - que justificam uma decisão mostrando que ela protege os direitos de um indivíduo ou de um grupo, e (2) argumentos de política que justificam certa decisão mostrando que ela protege ou fomenta um objetivo da comunidade como um todo, aqui entendidos como de políticas públicas, que buscam promover benefícios gerais.

A distinção entre argumento de princípios e argumentos de política é o que em um primeiro momento, autoriza o judicial review. Em regra, o juiz não deve agir como legislador, devendo limitar-se a aplicar as leis existentes, eis que o juiz não é investido de autoridade pública para legislar. Essa atividade jurisdicional, especialmente quando do exercício do judicial review, deve levar em consideração apenas os argumentos de princípio, de forma a impor direitos fundamentais contra decisões de uma maioria política que "pelo processo legislativo, pode suprimir os direitos fundamentais das minorias ${ }^{19}$ sob o pretexto da observância ao "interesse geral"'.

Neste ponto, Dworkin aponta grave falha da tese de Waldron. Segundo o autor, em virtude do princípio que veda a atividade legislativa em causa própria, as decisões de política e de princípio que tem potencial de ir de encontro à vontade da maioria não podem ser submetidas a sua própria deliberação. É que na sua conceção, este cenário revela que a legalidade restaria malferida, eis que os legisladores atuariam em benefício de si ou de seu próprio grupo político, impondo-se reconhecer que pelo menos quando direitos fundamentais das minorias restarem em risco (de extinção ou de redução), o Legislativo não será o lugar apropriado para tomar decisões de princípios.

Dworkin reconhece assim, que uma sociedade que se dignifica a ponto de assegurar direitos em um texto constitucional está necessariamente sujeita a lidar com problemas jurídicos e morais. Inevitavelmente, pelo que ele afirma, quando uma constituição firma direitos individuais, mas não estabelece instrumentos próprios para garanti-los ou não estabelece precisamente no que consistem, algum organismo de governo deve ter a última palavra sobre o que tal direito deva valer. Tal resposta pode ser dada pelos tribunais constitucionais sem que isso, portanto, signifique violação ao princípio da legitimação democrática.

Atualmente, o tradicional modelo de judicial review aliado a supremacia do poder judiciário tem sido um dos maiores alvos de críticas da teoria constitucional, não apenas sob a ótica da legitimidade democrática, mas também pelo seu resultado no que tange a verdadeira efetivação dos direitos fundamentais.

19 Idem, p. 104. 
É que referida capacidade, entendida por alguns como excessiva, passou a ser vista com maus olhos em razão de fenômenos como o ativismo judicial e a judicialização política, levando a doutrina a uma busca incessante por formas de combate a essas patologias. $\mathrm{Na}$ busca por uma solução conciliadora, surgem os arranjos institucionais dialógicos.

\section{A teoria do diálogo institucional e suas vertentes concretistas}

Ante a evidenciada necessidade de conferir maior estabilidade no processo jurídico-político de definição dos direitos, alguns Estados de tradição parlamentar convencidos da necessidade de implementação de um sistema de revisão judicial das leis para uma maior efetivação dos direitos fundamentais, buscaram desenvolver modelos alternativos aos até então existentes.

Neste cenário, um exemplo de macroestrutura democrática característica pela sua estrutura governamental singular é o Canadá, que adota mecanismos dialógicos de interpretação e significação da Constituição. Assim como Nova Zelândia e Reino Unido, que até então viviam sob a égide de um sistema pautado na supremacia do Parlamento, tais países instituíram um modelo de revisão judicial a partir do tradicional modelo americano, porém, tentando uma nova forma de equilíbrio entre os poderes, até então inexistente. Em rápida síntese, o novo modelo traduz-se basicamente em uma forma de controle de constitucionalidade onde existem mecanismos de respostas da população àquelas decisões que lhes parecem erradas, visando com isso diminuir a tensão natural relativa a legitimidade democrática do judicial review.

Nele, "a interpretação judicial das provisões constitucionais pode ser revisada pelo legislativo em um prazo relativamente curto, usando uma regra de decisão não muito diferente da que é usada no processo legislativo cotidiano"2o.

Neste aspeto, o diálogo institucional se limita à "comunicação" estabelecida entre o Tribunal Constitucional e o Parlamento, sobretudo porque o cerne do debate acerca da legitimidade democrática da jurisdição constitucional restringe-se a esses dois ramos do poder, ficando o poder executivo de fora. Assim, é possível sintetizar o diálogo institucional a um complexo arranjo no qual as grandes decisões de um tribunal constitucional podem ser rediscutidas por um órgão legislativo, e, por derradeiro, serem dotadas de um novo escopo

20 TUSHNET, Mark - Weak Courts, Strong rights: judicial review and social welfare rights in comparative constitutional law. Princeton: Princeton University Press, 2009, p. 39. 
político-jurídico instruído pelo construtivismo cooperativo em atenção a necessidade de máxima efetivação dos direitos fundamentais ${ }^{21}$. Melhor esclarece Peter $\mathrm{Hogg}^{22}$ :

"Onde uma decisão judicial é aberta a possibilidade de reversão, modificação ou repulsa legislativa aí reside o verdadeiro relacionamento dialógico entre Corte e Corpo Legislativo. Neste caso, a decisão judicial causa um verdadeiro debate público onde valores encartados na Constituição são mais proeminentes do que seriam se não houvesse a sobredita decisão judicial" (tradução livre).

A experiência dialógica aplicada no Canadá, foi inaugurada através do Canadian Charter of Rights and Freedoms. Este normativo, que pode ser compreendido como uma declaração de direito e liberdades fundamentais, faz parte da Constituição do Canadá e foi o resultado prático de pelo menos dois intensos anos de debate acerca das perspetivas governamentais de um país plural e contraditório.

Efetivamente adotada em 1982, a carta prevê em sua "Seção n. 33" o mecanismo de "exceção por declaração expressa", que resguarda a possibilidade de ter o parlamento a última palavra sobre decisões controvertidas da suprema corte. A referida seção estabeleceu a cláusula notwithstanding, também conhecida como la clause dérogatoire ou mesmo override power. Assim, prevê a Seção 33:23

"EXCEÇÃO POR DECLARAÇÃO EXPRESSA: O parlamento ou casa legislativa provincial pode expressamente declarar em ato interno que sua provisão normativa tem eficácia inobstada a existência prévia das provisões a que faz menção a seção 2 ou 7 a 15 desta Carta; PROCEDIMENTO DA EXCEÇÃO: (2) O ato legislativo que expressa a declaração de aplicação inobstante, feita sob os regramentos desta subseção, terá os mesmos efeitos que as provisões expressas nesta Carta. LIMITAÇÃO TEMPORAL DE CINCO ANOS: (3) A declaração por provisão normativa de eficácia inobstada feita nos termos da subseção (1) perderá sua

21 Ou seja, as teorias dialógicas partem da premissa de que, muitas vezes, a decisão judicial não será suficiente para a resolução de um conflito sobre direitos, sobretudo nos casos relativos à efetivação de direitos fundamentais, nos quais existem limitações que ultrapassam a seara da competência judicial, portanto, não pode a decisão judicial ser considerada o fim da linha dentro da jurisdição constitucional, principalmente quando se busca a máxima eficácia de direitos fundamentais.

22 HOGG, Peter W.; BUSHELL, Allison A. - The Charter Dialogue between Courts and Legislatures (Or Perhaps the Charter of Rights Isn't Such a Bad Thing after All). In Osgoode Hall Law Journal, Toronto. ISSN 0030-6185. V. 35, N. 1, 1997, p. 17.

23 CANADA - Consolidation of the Constitution Acts, 1967 to 1982. Department of Justice, 1989. [Consultado em: Março de 2019]. Disponível em: http://www.egov.ufsc.br/portal/sites/default/files/anexos/21363-21364-1-PB.htm 
eficácia após cinco anos a partir da entrada de sua vigência ou vez ultrapassado período inferior especificado na declaração; REPRISTINAÇÃO: (4) O parlamento ou casa legislativa provincial poderá conferir efeitos repristinadores a declaração feita nos termos da subseção (1). (5) A subseção (3) é aplicável nas hipóteses de declaração repristinada" (tradução livre).

Em breve sintese, a provisão da referida seção assegurou às legislaturas nacional e provincial ser possível a superação de uma lei ou parte dela por uma provisão legislativa durante um limitado período de tempo, previamente estabelecido - sustando assim, a eficácia de determinados direitos e consequentemente de qualquer de decisão da Suprema Corte. A decisão legislativa em apreço, pode somente afetar temporariamente alguns direitos fundamentais (e.g. os direitos fundamentais constantes da seção n. 2, como a liberdade de religiosa, de associação e de expressão) ou os chamados "direitos legais" (e.g. liberdade de locomoção em tempos de paz, vedação ao tratamento cruel ou degradante). Outros direitos, como os previstos na seção n. 6 da carta canadense (e.g. direitos inerentes a um regime democrático ou a pluralidade cultural-linguística) são insuscetíveis de limitação pelo legislativo.

Esse novo sistema de controle de controle de constitucionalidade foi considerado por autores como Peter Hogg e Alison Bushell, como uma invenção "única" no mundo jurídico. Na sua aceção, expressa na obra The charter dialogue between Courts and Legislatures ${ }^{24}$, tal modelo é caracterizador do sistema dialógico de judicial review.

Na tese de Hogg, a instituição do override power não significou um uso desmedido do poder de superação parlamentar. Com efeito, a partir do estudo do referido autor, foi consignado que em regra, depois de algumas declarações de inconstitucionalidade, o parlamento intentava as chamadas "legislative sequels" que não necessariamente significavam o emprego da cláusula 33 -, mas e.g., a aprovação de uma nova lei que encampa as objeções feita pelo tribunal constitucional em suas decisões. Segundo $\mathrm{Hogg}^{25}$ :

“(...) Normalmente existe uma lei alternativa que está disponível para o corpo legislativo e que permite que o propósito legislativo seja substancialmente realizado, embora por meios um pouco diferentes. Além disso, quando o Tribunal derruba uma lei, frequentemente oferece uma sugestão de como a lei poderia

24 HOGG, Peter W.; BUSHELL, Allison A. - The Charter Dialogue between Courts and Legislatures (Or Perhaps the Charter of Rights Isn't Such a Bad Thing after All). In Osgoode Hall Law Journal, Toronto. ISSN 0030-6185. V. 35, N. 1, 1997, p. 75-124.

25 Idem, p. 89. 
ser modificada para resolver os problemas constitucionais. O corpo legislativo frequentemente segue essa sugestão, ou elabora uma lei diferente que também contorna as barreiras constitucionais" (tradução livre).

Ao retirar-se dos tribunais constitucionais a prerrogativa da última palavra, submetendo as suas decisões à um processo de eventual resinificação por parte do Parlamento - processo no qual se resguarda os valores Constitucionais indicados pelo tribunal, estar-se-ia diante de um modelo democraticamente regulado de significação dos direitos.

A resposta legislativa, seja pelo acordo ou pelo desacordo, seria assim, fruto do diálogo consciente, um debate público e qualificado do direito. É dizer-se que a teoria do diálogo, quando das decisões em sede de judicial review, convida o poder legislativo à reflexão sobre eventuais distorções - o que no sentir de Roach ${ }^{26}$ permite "uma atuação em equipe dos poderes, na qual um compensa as fraquezas do outro". Assim, a partir da análise do arranjo político canadense, é possível notar que o principal objetivo das teorias dialógicas reside no estabelecimento de um processo público no qual todos participam na busca da melhor resposta aos grandes problemas constitucionais. Significa dizer que rejeita os extremos, tanto da atuação judicial como da atuação legislativa, "induzindo o tribunal constitucional e o parlamento a assumirem a responsabilidade política e apresentar justificativas razoáveis para suas escolhas no tocante à restrição de direitos" ${ }^{27}$.

Mas, afinal, como as estruturas de poder podem dialogar, e em que medida o diálogo público é possível? De princípio, cumpre notar que nem toda comunicação estabelecida entre os ramos de governo na tarefa de significação do direito pode ser considerada um diálogo institucional, em que pese possa ser considerada, em alguma medida, como uma interação.

Isso porque o fator que parece distinguir um diálogo de uma mera interação entre instituições/ramos de governo, reside no compromisso material de um construtivismo cooperativo. Isto é, o diálogo reside não na simples comunicação, mas sim na adesão estrutural de uma verdadeira vontade de resolução coletiva dos problemas constitucionais. Cumpre notar que a noção de construtivismo cooperativo, diante da historicidade do desenvolvimento das instituições de governo que cada organização política apresenta, permite que a vontade de resolução dos conflitos seja estabelecida por múltiplos meios, não existindo assim, uma única forma de diálogo ou interação.

26 ROACH, Kent - The Supreme Court on Trial: Judicial Activism or Democratic Dialogue. Irwin Law, 2001, p. 296. 27 Idem, p. 89. 
É diante desta pluralidade de formas que a doutrina constitucionalista contemporânea tende a classificar as expressões dialógicas sob várias perspetivas. Alguns notáveis autores como Luc Tremblay $^{28}$, Grégoire Webber ${ }^{29}$ e Gal Dor ${ }^{30}$, consideram, por exemplo, a divisão substancialista da teoria dialógica. Em rápida síntese, segundo eles, é possível notar a diferença entre um diálogo formal - que consiste na mera deferência do poder legislativo à decisão alcançada pelo tribunal constitucional, inexistindo assim, acrescimento ao resultado prático da interpretação alcançada -, e um diálogo material, ou substancial - que consiste no estabelecimento de um verdadeiro processo racional de conciliação entre o resultado de interpretação do tribunal constitucional e a vontade interpretativa do legislador, realizável através da argumentação crítica e sedimentável pelo consenso prático.

Em outra perspetiva, delineada sobretudo pelos estudos de Christine Bateup ${ }^{31}$, é possível ainda classificar as expressões dialógicas em outros dois grandes ramos: os chamados Diálogos de método judicial, e os Diálogos estruturais. É o que se passa a analisar.

\section{A. Os Diálogos de Método Judicial}

Com efeito, os chamados diálogos pautados no método judicial, podem ser compreendidos como técnicas dialógicas centradas no poder judiciário. Isto porque, em rápida síntese, pretendem fomentar o nascimento do diálogo a partir de ferramentas que estimulem um debate essencialmente endoprocessual com os demais ramos de governo e demais atores interpretativos da constituição.

Seja por meio da designação de peritos, da colheita de depoimentos de especialistas, ou ainda através de audiências públicas, estas técnicas pretendem "habilitar a corte a promover um debate mais amplo sobre o ordenamento constitucional" 32 sem, contudo, abandonar por completo a decisão judicial como resultado inescapável do processo. Os diálogos de método judicial por seu turno podem ser subdivididos em práticas de: i) aconselhamento judicial; ii) centralização processual; e iii) minimização judicial.

28 TREMBLAY, Luc; WEBBER, Grégoire C. N. - Introduction: La Fin de Oakes?. In La Limitation des Droits De la Charte: Essais Critiques Sur L’Arrêt R. C. Oakes. Montréal: Éditions Thémi, 2009.

29 Idem, p. 298.

30 DOR, Gal - Constitutional Dialogues in action: Canadian and Israeli experiences in comparative perspective. In Indiana International and Comparative Law Review, Indianapolis. ISSN 1061-4982. V. 11, N. 1, 2008, p. 1-36.

31 BATEUP, Christine - The dialogic promise: assessing the normative potential of theories of constitutional dialogue. In Brooklyn Law Review, New York. ISSN 0007-2362. V. 71, N. 3, 2006, p. 1109-1180.

32 BATEUP, Christine - The dialogic promise: assessing the normative potential of theories of constitutional dialogue. In Brooklyn Law Review, New York. ISSN 0007-2362. V. 71, N. 3, 2006, p. 1123. 


\section{a) Diálogo por aconselhamento judicial}

As práticas de diálogo por aconselhamento judicial sugerem que o tribunal constitucional se utilize de uma série das chamadas "técnicas proativas de interpretação e tomada de decisão"33 a fim de recomendar ou desaconselhar os demais ramos de governo acerca da adoção de determinados cursos de ação. Em linhas gerais, o aconselhamento judicial deve ser operacionalizado por meio de instruções essencialmente orientativas, isto é, não vinculantes, acerca da visão do tribunal constitucional sobre a constituição e seu significado. $\mathrm{O}$ principal e mais distinto objetivo desta prática é permitir que os demais ramos de governo compreendam a visão constitucional do tribunal e com isso elaborem, em suas respetivas competências, uma legislação não conflitante, ou ainda alterem a legislação em vigor para evitar futuras arguições de incompatibilidade.

Um exemplo prático desta prática de aconselhamento é oportunamente ilustrado pelo julgado da suprema corte americana em City of Chicago v. Morales. Em rápida síntese, no caso em questão, foi analisado pela corte a constitucionalidade da Chicago's gang-loitering law, norma que impedia a congregação pública de certas pessoas em face de questões de segurança pública. O julgamento, coordenado pelo voto da Supreme Justice Sandra O'Connor, reconheceu a incompatibilidade da citada lei ante a violação ao direito fundamental ao devido processo legal, e, mais em frente, esboçou de forma detalhada as alternativas legais que poderiam ser adotadas pelo legislador como forma de adaptar a norma à visão constitucional-política de mundo da suprema corte - técnica cunhada então como "constitutional road map decision".

Assim, o aconselhamento judicial pode ser efetivado por meio de duas grandes formas: uma, declarando a inconstitucionalidade de leis e demais atos normativos, e, ao mesmo tempo, sugerindo curso de ação alternativo para a finalidade legislativa pretendida; e a outra, declarando a constitucionalidade de leis e demais atos sugerindo ao legislador a adoção de emendas ou correções capazes de clarificar ainda mais a atividade de interpretação que pode ser eventualmente prejudicada por conta da ambiguidade ou obscurantismo léxico.

Contudo, apesar de ser classificado como ferramenta dialógica pela doutrina, talvez referida prática sequer devesse ser considerada uma forma de diálogo. É que sua adoção toma como pressuposto de validação a posição interpretativa de juízes como privilegiada, haja vista que ela, e somente ela, pode servir de "guia" para os demais ramos de governo. Em que pese ser o aconselhamento essencialmente orientativo, ele também pressupõe em

33 Ibidem. 
Uma abordagem conceitual da teoria do diálogo institucional na jurisdição constitucional portuguesa

PAULO ROBERTO BARBOSA RAMOS | PEDRO TROVÃO DO ROSÁRIO | PEDRO NILSON MOREIRA VIANA

GALILEU - e-ISSN 2184-1845 - Volume XX - Issue Fascículo 1 $1^{\text {ts }}$ January Janeiro - 30 th June Junho $2019 \cdot$ pp. 7-36

sua essência a ideia de que os demais ramos de governo não têm capacidade de interpretar o direito sem necessariamente contar com a assistência do poder judiciário.

É claro que ao final de toda atividade de interpretação, como afirmava Dworkin, faz-se necessário o estabelecimento de uma instituição dotada da autoridade estrutural da "última palavra". Contudo, certamente sem recair nos temores da anarquia interpretativa - em que cada ramo de governo interpreta e se guia conforme suas próprias convicções constitucionais, o judiciário não tem vocação para servir de único catalisador da atividade de interpretação do direito.

O aconselhamento judicial assim, se revela como uma perigosíssima forma de deslocamento do autogoverno, na medida em que insta o legislador a adotar suas "sugestões", sob pena de, no futuro, ter a legislação que enfrentar uma arguição de incompatibilidade. É preciso notar, acima de tudo, que a existência de um verdadeiro diálogo institucional pressupõe uma relação de coordenação racional e não de submissão hierárquica.

\section{b) Diálogo por centralização processual}

Em outro modo, as chamadas práticas de centralização processual, ao invés de defenderem a postura proativa do Judiciário como centro objeto do "diálogo", pretendem assegurar maior espaço para as legislaturas realizarem a tarefa de significação do direito.

A centralização processual assim, pode ser precisamente conceituada pela lição de Christine Bateup ${ }^{34}$ :

“Em teorias centradas no processo, os juízes são encorajados a avaliar se os agentes políticos adequadamente prestaram atenção no impacto que suas políticas legislativas terão sobre valores constitucionais substantivos. Se for demonstrado que não tiveram a devida atenção ou deliberação sobre tais valores, então o judiciário pode forçar os demais ramos de governo a reconsiderar suas decisões com o nível adequado de atenção que estes valores exigem" (tradução livre).

As práticas de centralização processual são exercidas de forma dúplice. Em primeiro aspeto, evitando que juízes decidam antecipadamente e por derradeiro uma matéria sem o devido debate público; e ainda, envolvendo os ramos políticos e seus agentes mais explicitamente no debate constitucional. 


\section{c) Diálogo por minimização judicial}

Por fim, as práticas de minimização judicial consistem na saída de juízes do cenário de decisão a fim de permitir maior espaço de escolha e deliberação democrática acerca do conteúdo dos direitos.

Significa dizer que o poder judiciário deve adotar posturas passivas, isto é, adotar cursos de 'não-ação'. Conhecidas como "passive virtues", tais posturas pretendem evitar a saturação pública do envolvimento dos tribunais constitucionais com questões de valores altamente controvertidas ao passo em que permitem que os demais ramos de governo e a sociedade desenvolvam canais mais democráticos de escolha. Teóricos como Michael Heise e Alexander Bickel, defensores do diálogo por práticas de minimização judicial, acreditam que o espaço que pode ser aberto pela passividade/inércia dos tribunais constitucionais é capaz de fomentar um momento no qual os demais poderes se tornem mais determinantes no processo de resolução de questões controvertidas.

Dessa forma, o minimalismo consiste em um esforço para limitar a amplitude e profundidade das decisões judiciais. Quando os juízes carecem, e sabem que carecem, de informações relevantes, o minimalismo é "uma forma de resposta apropriada, razoável e, até mesmo, inevitável para resolver o problema prático de obter o consenso dentro de uma sociedade heterógena" ${ }^{\prime 35}$. Em um primeiro aspeto, é possível constatar que a tese minimalista tem um objetivo dialógico evidente, posto que almeja construir uma ambientação favorável a participação do legislativo e executivo no processo de resolução dos conflitos constitucionais.

No entanto, a minimização parece ser demasiada extremada, chegando até a anular, por decorrência, o próprio resultado dialógico que objetiva, vez que pretende retirar da equação democrática o poder judiciário enquanto membro integrante indissociável da tarefa interpretativa. É possível afirmar que a ideia de minimização levada às últimas proporções, é o extremo oposto do ideário de supremacia judicial, eis que isola da premissa do diálogo a ideia de que é necessário integrar os ramos de governo para dialogar, não os segregar.

Não parece ser possível conceber assim um mecanismo institucional democrático e verdadeiramente dialógico quando seu axioma parte do imperativo da omissão de um ou mais poderes. Este, na verdade, é o sintoma disfuncional que se pretende combater, não promover.

35 SUSTEIN, Cass - One case at a time: judicial minimalism on the Supreme Court. Cambridge: Harvard University Press, 1999, p. 31. 


\section{B. Os Diálogos Estruturais}

Com efeito, do contrário dos diálogos centrados do método judicial, os diálogos estruturais concentram um conjunto de práticas que acreditam fomentar o diálogo institucional fora do eixo do judicial. Isto é, seus partidários acreditam que tais práticas são capazes fomentar o diálogo por meio da resposta de atores políticos a decisões constitucionais controvertidas, ambientando uma quadra de interação entre juízes, legisladores e burocratas. A construção coordenada, prática que melhor exemplifica o diálogo estrutural, pode ser considerada a mais progressista. Segundo Bateup, a prática se refere à conceção de ser a tarefa de "interpretar a constituição uma atividade compartilhada entre a corte constitucional e os demais ramos de governo" 36 .

Em rápida análise, a tese da interpretação compartilhada, exposta primeiramente por James Madison - autor federalista, pretende autorizar que cada ramo de governo, dentro de suas respetivas atribuições constitucionais, seja livre para interpretar e aplicar o direito desimpedidamente. Como bem destaca Bateup ${ }^{37}$ :

"Embora o reconhecimento de que as questões de interpretação constitucional caíssem normalmente para o Judiciário no curso normal do governo, James Madison rejeitou a opinião de que as decisões judiciais tinham um status único, já que a Constituição [americana] não previa nenhuma autoridade específica para determinar o limite da divisão de poder entre os diferentes ramos. Similarmente, Thomas Jefferson considerou que cada ramo do governo deve ser "coordenado e independente um do outro", e que cada ramo tem a responsabilidade primordial de interpretar a Constituição no que concerne às suas funções" (tradução livre).

Significa que em face da constituição de um governo repartido em três esferas harmônicas e independentes entre si, um ramo de governo não teria legitimidade constitucional para impor sobre os demais sua visão jurídico-política de valores.

Isto impõe reconhecer que em face da disposição orgânica de funções, o Judiciário, o Legislativo e o Executivo estão autorizados a interpretar a constituição e aplicá-la conforme suas próprias deliberações, vez que todos encontram nela seu fundamento de validade e existência. Esta conceção originária de construção coordenada é amplamente criticada, vez que é imprecisa "sobre que assuntos ou valores constitucionais cada ramo de governo

36 BATEUP, Christine - The dialogic promise: assessing the normative potential of theories of constitutional dialogue. In Brooklyn Law Review, New York. ISSN 0007-2362. V. 71, N. 3, 2006, p. 1137.

37 Ibidem. 
Uma abordagem conceitual da teoria do diálogo institucional na jurisdição constitucional portuguesa

PAULO ROBERTO BARBOSA RAMOS | PEDRO TROVÃO DO ROSÁRIO | PEDRO NILSON MOREIRA VIANA

GALILEU - e-ISSN 2184-1845 - Volume XX - Issue Fascículo 1 - 1st January Janeiro - 30th June Junho $2019 \cdot$ pp. 7-36

deterá a última palavra" ${ }^{38}$. Esta imprecisão é capaz de gerar o fenômeno da "anarquia interpretativa", que consiste nos múltiplos resultados que cada ramo de governo pode fazer sobre a interpretação dos demais, inexistindo assim uma única solução as controvérsias constitucionais suscitadas.

A solução sugerida pelos partidários das práticas coordenadas, ante o iminente risco de anarquia interpretativa, é permitir a existência de mecanismos de checks-and-balances sobre o tribunal constitucional por parte dos demais ramos em caso de discordâncias sobre valores constitucionais substantivos.

Isto, segundo eles, permitiria que o legislativo e executivo por exemplo, arrostassem a autoridade e limites da interpretação do tribunal constitucional pela recusa de cumprimento, pelas ameaças de "empacotamento do tribunal", por novas leis e estatutos capazes de resinificar o escopo jurídico de decisões interpretativas, tudo a fim de demover a hermenêutica constitucional dos tribunais, permitindo assim, o compartilhamento da "autoridade interpretativa". Segundo Christine Bateup ${ }^{39}$ :

"Nestas circunstâncias, o Tribunal só será alvo de cheks-and-balances se estiver interpretado a constituição de modo muito dispare da interpretação consentida pelos demais ramos políticos e forças sociais. Além disso, o Tribunal pode não ser sequer objeto de cheks-and-balances se a inércia legislativa sobre uma determinada questão é muito grande, ou se os ramos políticos preferem deixar ao judiciário o controle sobre uma determinada questão" (tradução livre).

Sem grande esforço interpretativo é possível verificar que a visão da construção coordenada do diálogo pretende implementar um verdadeiro modelo consensual de constitucionalidade, onde a racionalidade do direito pode ser facilmente relegada em função de múltiplos outros interesses.

Se levada às últimas consequências, torna-se evidente ainda os consideráveis riscos à unidade e previsibilidade de um sistema constitucional, posto que embora tenha o pretexto de permitir em alguma medida o compartilhamento da autoridade interpretativa, ao fim e ao cabo, permite que a definição de valores e princípios constitucionais substantivos esteja sempre ao alvitre dos fatores reais de poder.

Essa sugestão de atividade interpretativa, especialmente quando do conflito recorrente de questões polêmicas - compreendidas como aquelas que envolvem, e.g., questões de 
Uma abordagem conceitual da teoria do diálogo institucional na jurisdição constitucional portuguesa

PAULO ROBERTO BARBOSA RAMOS | PEDRO TROVÃO DO ROSÁRIO | PEDRO NILSON MOREIRA VIANA

GALILEU - e-ISSN 2184-1845 - Volume XX - Issue Fascículo 1 - 15t January Janeiro - 30th June Junho $2019 \cdot$ pp. 7-36

escopo éticos, étnico, religioso, histórico -, tem grande potencial de vulnerar direitos fundamentais em face do consentimento público acerca de sua (im)pertinência.

\section{A jurisdição constitucional portuguesa e o diálogo institucional: considerações finais}

Conforme notado, o diálogo institucional, enquanto resultado prático de um movimento global de aperfeiçoamento dos mecanismos democráticos, tem grandes pretensões.

Ao tentar reequilibrar os Poderes, reconhecendo as competências específicas de cada um no âmbito da jurisdição constitucional e sugerindo uma atuação conjunta de consenso, a teoria revela uma multiplicidade de faces que vão desde os diálogos de método judicial, até os estruturais. Isto permite concluir que não existe uma forma única para a ocorrência do diálogo, podendo ele se manifestar por meio das mais diversas práticas e sob perspetivas teóricas diferentes, a depender da cultura histórica e política do país em que está inserido. Diretamente influenciado pelo movimento constitucionalista, enquanto projeto humano em desenvolvimento, o diálogo institucional se apresenta como produto das várias diferenças históricas, culturais e sociopolíticas presentes nas mais variadas realidades constitucionais.

Por este motivo é que também é possível afirmar que não existe somente um, mas sim, múltiplos processos dialógicos, com características e desafios próprios, uma vez que tal conceito expressa em si as grandes finalidades do estado democrático de direito contemporâneo: limitar o poder, fortalecer as macroestruturas democráticas e maximizar a eficácia dos direitos fundamentais. Assim, diante do cenário de progressivo avanço da globalização, as necessidades que a tese dialógica pretende suprir se tornam cada vez mais comuns entre os países, delineando-se por meio dos desafios uma verdadeira comunidade de valores constitucionais compartilhados entre as várias constituições do nosso tempo. Este elo que os une é, antes de tudo, antropológico, e por tal condição permite constatar a presença do fenômeno dialógico em inúmeras ordenações, sejam de origem romano-germânica ou anglo-saxônica.

Neste aspeto, conceber em que medida a matriz dialógica pode se fazer presente em um sistema constitucional, pressupõe, antes de tudo, conceber as origens e fundamentos de sua jurisdição constitucional - eis que é através dela que uma sociedade se organiza racionalmente na tarefa de dar significado aos direitos. Assim, diante do contexto histórico e teórico analisado, resta saber: é possível haver diálogo institucional no sistema de definição dos direitos em Portugal? 
Longe das pretensões de esgotar a reflexão exposta, é imperativo compreender preliminarmente em que contexto a jurisdição constitucional lusitana se encontra, para somente a partir daí avaliar, em uma análise estritamente normativa, se alguma das quatro maiores expressões dialógicas analisadas anteriormente é constatável de modo substantivo no processo público de fiscalização abstrata da constitucionalidade, vez que aí se realiza a análise judicial direta e abstrata da atuação legislativa, ponto de maior relevância e potencial confronto entre a atuação do Tribunal Constitucional e sua relação com o Poder Legislativo.

Pois bem. Portugal, assim como Brasil, foi dotado de inúmeras constituições.

Este histórico de instabilidades políticas vivenciado no país ibérico, é muito bem sistematizado por Jorge Miranda ${ }^{40}$, para quem é possível distinguir entre as sucessivas constituições, pelo menos três grandes momentos:

"No primeiro, de forte influência francesa, tenta-se estabelecer com alguma deficiência, o liberalismo político e econômico, pretendendo-se assegurar a liberdade, a segurança, e a propriedade dos cidadãos. No segundo, apesar de haver um texto constitucional, as liberdades e garantias sofrem fortíssimas restrições e verifica-se uma completa concentração de poderes no Presidente da República e, por algum tempo, no Presidente do Conselho de Ministros(...). No terceiro, representado pelo advento da Constituição Portuguesa de 1976, tem-se a abertura para horizontes novos de Estado social. Somente nesta altura pode falar-se em constitucionalismo democrático posto que referida constituição se apresenta como a mais complexa de todas as constituições portuguesas, sendo tanto uma Constituição-garantia quando uma Constituição prospectiva".

O terceiro e atual momento do constitucionalismo português, repousa sobre as bases estruturais assentadas pela Constituição de 1976.

Promulgada em dois de abril de 1976, a constituição de Portugal surgiu em um contexto revolucionário de completa repulsa a um passado ditatorial que vigeu desde 1933 a 1974, período em que o Estado constitucional, representativo e de direito restou sistematicamente vulnerado, especialmente, pela concentração de poderes. Em face desde período, a nova constituição representou um modelo duplo, sendo definida por alguns teóricos como constituição-garantia e prospetiva, uma vez que se preocupou em restaurar direitos e liberdades fundamentais, sem deixar de lado as necessidades de completa reformulação do sistema de limitação dos poderes políticos. Jorge Miranda esclarece mais uma vez o novo 
momento paradigmático inaugurado no constitucionalismo português, quando destacou que “(...) a constituição de 1976, num tempo em que tudo parecia possível, procurou também vivificar a enriquecer o conteúdo da democracia, multiplicando as manifestações de igualdade efetiva, participação, intervenção e socialização, numa visão ampla. (...)"41.

Assim, estruturada em quatro grandes partes ${ }^{42}$, o centro ideológico da referida carta constitucional foi direcionado ao estabelecimento de um Estado de direito democrático pautado de sobremodo i) na garantia e efetivação dos direitos fundamentais, ii) na separação e interdependência dos poderes, e iii) na garantia da tutela jurisdicional efetiva. Neste aspeto, diante da tendência inerente de centralização do Poder vivenciada na história portuguesa recente - história esta, diga-se de passagem, indissociável do contexto jurídico-político da quadra atual de definição dos direitos - é que se revela imperativo notar a importância substantiva que o sistema de controle de constitucionalidade tem na manutenção das estruturas institucionais do país.

Em brevíssima síntese, a fiscalização da constitucionalidade das leis pelos tribunais foi consagrada em Portugal pela Constituição de 1911, a primeira Constituição republicana portuguesa. Contudo, foi apenas com a Constituição de 1976, no bojo de um Estado de Direito democrático, que tal fiscalização viria a ter pleno desenvolvimento, vez que conjugaria os "poderes [revisionais] de todos os tribunais (artigo n. 204 da Constituição Portuguesa) $)^{43}$ e do Tribunal Constitucional (artigo n. 280 da Constituição Portuguesa) ${ }^{44}$ - ao qual pertence sempre a última palavra"45.

A partir da análise de Miranda, é possível observar que o processo de fiscalização de constitucionalidade português, assim como o brasileiro, é sincrético, posto que admite simultaneamente que i) todos os tribunais, seja qual for a sua categoria (artigo n. 209 da Constituição Portuguesa) ${ }^{46}$, exerçam fiscalização em casos concretos, isto é, um controle de constitucionalidade incidental à matéria controvertida; e que ii) uma única instituição,

41 Idem, p. 202.

42 São elas: i) direitos e deveres fundamentais; ii) organização econômica; iii) organização do poder político; e iv) garantia e revisão da constituição.

43 Artigo n. ${ }^{\circ}$ 204: "Apreciação da inconstitucionalidade; Nos feitos submetidos a julgamento não podem os tribunais aplicar normas que infrinjam o disposto na Constituição ou os princípios nela consignados".

44 Artigo n. ${ }^{\circ}$ 280: "Fiscalização concreta da constitucionalidade e da legalidade 1 . Cabe recurso para o Tribunal Constitucional das decisões dos tribunais: (...) 6. Os recursos para o Tribunal Constitucional são restritos à questão da inconstitucionalidade ou da ilegalidade, conforme os casos".

45 MIRANDA, Jorge - O Regime de fiscalização concreta da constitucionalidade em Portugal. Instituto Jurídico de Ciências Jurídico-políticas: Lisboa, 2012, p. 6.

46 Artigo n. ${ }^{\circ}$ 209: "Categorias de tribunais; 1 . Além do Tribunal Constitucional, existem as seguintes categorias de tribunais: a) O Supremo Tribunal de Justiça e os tribunais judiciais de primeira e de segunda instância; b) O Supremo Tribunal Administrativo e os demais tribunais administrativos e fiscais; c) O Tribunal de Contas". 
com status hierárquico superior, seja incumbida da análise da constitucionalidade em tese de uma norma jurídica - instituição tal materializada no Tribunal Constitucional.

O controle de constitucionalidade abstrato de normas jurídicas, realizado pelo Tribunal Constitucional, se dá exclusivamente na perspetiva de um interesse público e objetivo, razão pela qual a fiscalização abstrata vincula-se a um poder funcional de iniciativa atribuído a determinados órgãos ou a frações de titulares de órgãos do poder político. De forma também semelhante ao modelo brasileiro, é possível identificar um poder geral de iniciativa atribuído a determinados órgãos ou titulares de órgãos, previstos no artigo 281 da Constituição da República Portuguesa ${ }^{47}$.

Cumpre notar que o processo de controle concentrado de constitucionalidade não é apenas desencadeado pelos detentores do poder funcional de iniciativa. Estes legitimados são ainda os responsáveis por fixar o objeto do processo no pedido, muito embora o Tribunal Constitucional não seja adstrito tal delimitação em vista da natureza objetiva deste controle. Isto permite denotar que o tribunal constitucional pode fundamentar a sua decisão em normas constitucionais diversas da invocada, reconhecendo ainda outras normas que, por efeito de reflexo, sejam também inconstitucionais.

Conforme preceitua a Lei n. 28 de 15 de novembro de 1982, o pedido de apreciação da constitucionalidade é dirigido ao Presidente do Tribunal Constitucional, devendo conter além da norma cuja apreciação se requer, as normas ou os princípios constitucionais violados. A partir deste instante, o juiz presidente faz analisar da admissibilidade do pedido, momento no qual evidencia aspetos processuais como a legitimidade ativa, interesse, e regularidade formal do pedido. Vez superados, e regularmente admitido o pedido, o juiz presidente notifica o órgão de que tiver emanado a norma impugnada para, querendo, se pronunciar sobre ele no prazo de trinta dias.

A partir de então, é designado ao feito um relator, para assim ser pautado e encaminhado para votação junto ao órgão plenário, que, em sessão solene, reúne todos os treze juízes integrantes para nova análise da admissão e julgamento do mérito do pedido.

47 Artigo n. ${ }^{\circ}$ 281: "Fiscalização abstrata da constitucionalidade e da legalidade: 2 . Podem requerer ao Tribunal Constitucional a declaração de inconstitucionalidade ou de ilegalidade, com força obrigatória geral: a) $\mathrm{O}$ Presidente da República; b) O Presidente da Assembleia da República; c) O Primeiro-Ministro; d) O Provedor de Justiça; e) O Procurador-Geral da República; f) Um décimo dos Deputados à Assembleia da República; g) Os Representantes da República, as Assembleias Legislativas das regiões autónomas, os presidentes das Assembleias Legislativas das regiões autónomas, os presidentes dos Governos Regionais ou um décimo dos deputados à respetiva Assembleia Legislativa, quando o pedido de declaração de inconstitucionalidade se fundar em violação dos direitos das regiões autónomas ou o pedido de declaração de ilegalidade se fundar em violação do respetivo estatuto". 
Diante da breve análise normativa fixada na Constituição da República e na norma processual que organiza a atividade judicante do Tribunal Constitucional, não é possível verificar a existência de nenhuma das práticas dialógicas, pelo menos em seu aspeto formal.

Isso porque é ausente do escopo de estudo das normas em questão as dimensões i) da proatividade interpretativa e decisional - próprias das práticas de "diálogo" por aconselhamento, ii) da centralização processual, vez que o processo através do qual se avalia a constitucionalidade abstrata de leis e atos normativos se dá, em seu aspeto material e processual, inteiramente no Tribunal Constitucional - o que estruturalmente não assegura espaço para as legislaturas realizarem a tarefa de significação do direito; iii) da minimização judicial, haja vista que em função do disposto no artigo n. 20 da Constituição da República Portuguesa $^{48}$ a atividade jurisdicional do estado é inafastável, impedindo a aplicação das chamadas "passive virtues" defendida por Michael Heise e Alexander Bickel; e, tampouco, do iv) diálogo estrutural, posto que a fiscalização de constitucionalidade abstrata ocorre no Tribunal Constitucional, não existindo qualquer compartilhamento da tarefa interpretativa que, por sinal, é de competência orgânica exclusiva do citado tribunal pelo que define o disposto no artigo n. 281 da Constituição da República Portuguesa ${ }^{49}$.

Assim, frise-se que, pelo menos sob o aspeto normativo, não é possível falar em diálogo institucional em Portugal, à luz das quatro maiores expressões dialógicas estudadas. Contudo, tal constatação não exclui desta realidade constitucional a existência de interações entre os poderes ou mesmo a presença material do diálogo através de outras formas de expressão dialógica.

Por ilustrativo, é possível identificar na fundamentação do voto dos juízes conselheiros do Tribunal Constitucional Maria Lúcia Amaral e Rui Manuel Moura Ramos - quando do acórdão em sede de controle de constitucionalidade preventivo n. 121 de 8 de abril de 2010 (Processo 192/10) $)^{50}$ que apreciou a constitucionalidade da lei permissiva do casamento civil entre pessoas do mesmo sexo -, uma verdadeira simbiose teórica entre as práticas de minimização judicial e de diálogo estrutural.

É que os referidos juízes conselheiros expressaram que estabelecer legalmente a possibilidade de casamento de pessoas do mesmo sexo é uma faculdade e não uma obrigação

48 Artigo n. ${ }^{\circ}$ 20: "Acesso ao direito e tutela jurisdicional efetiva; 1. A todos é assegurado o acesso ao direito e aos tribunais para defesa dos seus direitos e interesses legalmente protegidos, não podendo a justiça ser denegada por insuficiência de meios económicos (...) 5. Para defesa dos direitos, liberdades e garantias pessoais, a lei assegura aos cidadãos procedimentos judiciais caracterizados pela celeridade e prioridade, de modo a obter tutela efetiva e em tempo útil contra ameaças ou violações desses direitos (...)".

49 Artigo n. ${ }^{\circ}$ 281: "Fiscalização abstrata da constitucionalidade e da legalidade; 1 . O Tribunal Constitucional aprecia e declara, com força obrigatória geral: a) A inconstitucionalidade de quaisquer normas (...)".

50 Disponivel em: http://www.tribunalconstitucional.pt/tc/acordaos/20100121.html. 
constitucional do legislador, não tendo, portanto, o Tribunal Constitucional legitimidade para "interferir" no âmbito da conveniência e oportunidade legislativas ainda que sob pena de manter-se inegável violação a essenciais direitos, como, por exemplo, a igualdade jurídica de tratamento e autonomia privada.

Veja-se: “(...)Votámos a decisão no entendimento de que a opção legislativa sujeita à apreciação do Tribunal - a possibilidade de duas pessoas do mesmo sexo celebrarem um contrato de casamento - não é desconforme com a Constituição, sem que seja no entanto constitucionalmente imposta (...). Trata-se, pois, de uma escolha que, versando sobre matéria que não integra o núcleo indisponível do instituto constitucionalmente protegido, se encontra no âmago da liberdade de conformação política do legislador democrático. Nestes termos, é ela revisível por decisão soberana do mesmo legislador. Não cabe a este Tribunal interferir no âmbito das decisões do legislador democrático que, por opção constitucional, permanecem livres, nem mesmo nos casos em que a comunidade jurídica implicada é coincidente com todo o género humano e as matérias a decidir se revistam para a sua existência de inegável centralidade. Tais circunstâncias, se não autorizam que o Tribunal abandone a sua condição de legislador negativo, seguramente que se repercutem sobre a responsabilidade que, perante a comunidade, detém o legislador positivo democraticamente legitimado".

Outra notável expressão substantiva de diálogo por minimização judicial foi exposta na declaração de voto do juiz conselheiro José Borges Soeiro, quando da mesma controversa constitucional julgou, com amparo nos acórdãos n.105/1990 ${ }^{51}$ e n. 359/2009 ${ }^{52}$, somente ser cabível a declaração de inconstitucionalidade em face de indiscutível "não-concretização" ou "subversão" da matriz axiológica constitucional por onde o legislador deve sempre se orientar. Segundo ele, contudo, enquanto ainda houver considerável divergência pública sobre o conceito, implicações e decorrências de um princípio aberto em determinado problema jurídico, cumpre só ao legislador democrático optar e decidir.

Veja-se: “(...) no controlo jurisdicional da constitucionalidade das soluções jurídico-normativas a que o legislador tenha, desse modo, chegado, há que se operar com uma particular cautela e contenção. Decerto, assim, que só onde ocorrer uma real e inequívoca incompatibilidade de tais soluções com o princípio regulativo constitucional que esteja em causa (...) só então, quando for indiscutível que o legislador, afinal, não 'concretizou', e antes 'subverteu', a matriz axiológica constitucional por onde devia orientar-se, será lícito aos tribunais (e ao Tribunal Constitucional em particular) concluir pela inconstitucionalidade

51 Disponível em: http://www.tribunalconstitucional.pt/tc/acordaos/19900105.html.

52 Disponivel em: http://www.tribunalconstitucional.pt/tc/acordaos/20090359.html. 
das mesmas soluções.(...) E, se estas considerações são em geral pertinentes, mais o serão ainda quando na comunidade jurídica tenham curso perspetivas diferenciadas e pontos de vista díspares e não coincidentes sobre as decorrências ou implicações que dum princípio «aberto» da Constituição devem retirar-se para determinado domínio ou para a solução de determinado problema jurídico. Nessa situação sobretudo - em que haja de reconhecer-se e admitir-se como legítimo, na comunidade jurídica, um 'pluralismo' mundividencial ou de conceções - sem dúvida cumprirá ao legislador (ao legislador democrático) optar e decidir".

Assim, resta evidenciado que diante do marcante caráter histórico da teoria em estudo, sua ocorrência é fenômeno que precisa ser analisado com devida cautela de modo a não obliterar a existência substantiva, ainda que pontual, de múltiplas expressões não convencionais de diálogo.

\section{REFERÊNCIAS BIBLIOGRÁFICAS}

BASTOS, Celso Ribeiro - Curso de Direito Constitucional. 22. ${ }^{\text {a }}$ ed. São Paulo: Saraiva, 2010.

BATEUP, Christine - The dialogic promise: assessing the normative potential of theories of constitutional dialogue. In Brooklyn Law Review, New York. ISSN 0007-2362. V. 71, N. 3, 2006, p. 1109-1180.

CANADA - Consolidation of the Constitution Acts, 1967 to 1982. Department of Justice, 1989. [Consultado em: Março de 2019]. Disponível em: http://www.egov.ufsc.br/portal/sites/default/files/anexos/21363-21364-1-PB.htm.

CANOTILHO, J. J. G. - Direito constitucional e teoria da constituição. 7. ${ }^{a}$ ed. Coimbra: Almedina, 2003.

DOR, Gal - Constitutional Dialogues in action: Canadian and Israeli experiences in comparative perspective. In Indiana International and Comparative Law Review, Indianapolis. ISSN 1061-4982. V. 11, N. 1, 2008, p. 1-36.

DWORKIN, Ronald - Taking Rights Seriously. Cambridge: Harvard University Press, 1978.

HÄRBELLE, Peter - Hermenêutica Constitucional - A sociedade aberta dos intérpretes da Constituição: contribuição para a interpretação pluralista e "procedimental" da Constituição. Porto Alegre: Sérgio António Fabris Editor, 2002.

HÄRBELLE, Peter - Novos Horizontes e Novos Desafios do Constitucionalismo. In Anuário Português de Direito Constitucional - Vol. V. Coimbra: Coimbra Editora, 2006.

HOGG, Peter W.; BUSHELL, Allison A. - The Charter Dialogue between Courts and Legislatures (Or Perhaps the Charter of Rights Isn't Such a Bad Thing after All). In Osgoode Hall Law Journal, Toronto. ISSN o030-6185. V. 35, N. 1, 1997, p. 75-124.

MIRANDA, Jorge - Manual de Direito Constitucional. 1. ${ }^{a}$ ed. Coimbra: Coimbra Editora, 2008.

MIRANDA, Jorge - O Regime de fiscalização concreta da constitucionalidade em Portugal. Instituto Jurídico de Ciências Jurídico-políticas: Lisboa, 2012.

NEVES, Marcelo - Transconstitucionalismo. São Paulo: WMF Martins Fontes, 2013.

PORTUGAL - Tribunal Constitucional. Acórdão n. 105/90. Juiz Relator: Conselheiro Bravo Serra. Lisboa, 29 de março de 1990. [Consultado em: Março de 2019]. Disponível em: http://www.tribunalconstitucional. $\mathrm{pt} / \mathrm{tc} /$ acordaos/19900105.html. 
PORTUGAL - Tribunal Constitucional. Acórdão n. 121/2010. Juiz Relator: Conselheiro Vítor Gomes. Lisboa, 8 de abril de 2010. [Consultado em: Março de 2019]. Disponível em: http://www.tribunalconstitucional. $\mathrm{pt} / \mathrm{tc} /$ acordaos/20100121.html.

PORTUGAL - Tribunal Constitucional. Acórdão n. 359/2009. Juiz Relator: Conselheiro Carlos Pamplona de Oliveira. Lisboa, 9 de julho de 2009. [Consultado em: Março de 2019]. Disponível em: http://www. tribunalconstitucional.pt/tc/acordaos/20090359.html.

RAMOS, Paulo Roberto Barbosa - Direito Constitucional Americano. São Luís: EDUFMA, 2016.

RAMOS, Paulo Roberto Barbosa; VIANA, Pedro Nilson Moreira - Diálogos Institucionais: um escorço de sua delimitação teórico-histórica à luz do constitucionalismo norte-americano. In Revista de Direito Constitucional e Internacional, São Paulo. ISSN 1518-272X. A. 26, V. 108, 2018, p. 323-345.

ROACH, Kent - The Supreme Court on Trial: Judicial Activism or Democratic Dialogue. Irwin Law, 2001.

SUSTEIN, Cass - One case at a time: judicial minimalism on the Supreme Court. Cambridge: Harvard University Press, 1999.

TREMBLAY, Luc; WEBBER, Grégoire C. N. - Introduction: La Fin de Oakes? In La Limitation des Droits De la Charte: Essais Critiques Sur L'Arrêt R. C. Oakes. Montréal: Éditions Thémi, 2009.

TUSHNET, Mark - Weak Courts, Strong rights: judicial review and social welfare rights in comparative constitutional law. Princeton: Princeton University Press, 2009.

VIEYTEZ, Eduardo J. Ruiz - La excepción constitucional australiana: el debate sobre la protección jurídica de los derechos y el modelo del diálogo institucional. In Revista Española de Derecho Constitucional, Madrid. ISSN 0211-5743. N. 95, 2012, p. 95-138.

WALDRON, Jeremy - A dignidade da legislação. São Paulo: Martins Fontes, 2003.

WALDRON, Jeremy - A Essência da Oposição ao Judicial Review. In Legitimidade da Jurisdição Constitucional. Rio de Janeiro: Lumen Juris, 2010.

WALDRON, Jeremy - Law and disagreement. Oxford: Oxford University Press, 2004. 